\title{
Smart city? - realia współczesnego przekazu informacji w ksztaltowaniu polityki przestrzennej polskich gmin
}

\section{Smart city? - the realities of contemporary information transfer in shaping the spatial policy of polish municipalities}

\begin{abstract}
Streszczenie
Dynamiczny rozwój systemów informatycznych nie pozostaje bez wpływu na zachodzące przemiany społeczno - gospodarcze, kształtując możliwości nowoczesnego zarządzania również w sferze rozwoju przestrzennego.

$\mathrm{Na}$ tym tle prezentowane badanie podjęło próbę odpowiedzi na pytanie jak opisywany postęp cywilizacyjny wpływa na ramy funkcjonowania polityki przestrzennej polskich gmin. Badanie ograniczono do zagadnień związanych ze współczesnym przekazem informacji i jego wpływem na zaangażowanie społeczne w proces planowania przestrzennego oraz na świadomość prawną władz samorządowych w realizowanej samodzielnie polityce przestrzennej.

W świetle zgromadzonych wyników zdiagnozowano znaczący rozdźwięk między współczesnym potencjałem informatycznym, a rzeczywistymi działaniami samorządów lokalnych, prowadzący do dezintegracji procesów planistycznych i konfliktów społecznych. W pracy przedstawiono również zarys proponowanych, niezbędnych działań naprawczych.
\end{abstract}

\begin{abstract}
The dynamic development of information systems affects the ongoing socio-economic changes, shaping the possibilities of modern management also in the sphere of spatial development.

Against this background, the presented study attempted to answer the question of how the described civilizational progress affects the framework of the functioning spatial policy of Polish municipalities. The study was confined to matters associated with contemporary information transfer and its effects on public involvement in the process of spatial planning, as well as on the legal awareness of municipal government personnel in their individually applied spatial policy.

In light of the collected results, a significant discrepancy was diagnosed between the contemporary IT potential and actual measures taken by municipal governments, leading to the disintegration of planning processes and social conflicts. The work features an outline of proposed necessary reparative measures.
\end{abstract}

Słowa kluczowe: przekaz informacji, polityka przestrzenna, partycypacja społeczna, zmiany systemowe Keywords: information transfer, spatial policy, public participation, systemic changes

\section{Wprowadzenie}

Pojęcie "smart", w odniesieniu do szeroko rozumianego procesu kształtowania przestrzeni, w przeważającej mierze dotyczy zaawansowanych technologii przekazu informacji ${ }^{1}$, wpływających na działania różnorodnych instytucji oraz na procedury gromadzenia i adaptacji niezbędnej wiedzy². Informacja stanowi wartość szczególnie cenną, mogącą niejednokrotnie decydować o przewadze ekonomicznej i szybszym rozwoju gospodarczym ${ }^{3}$. W konsekwencji, zarówno w Polsce, jak i na całym świecie, technologie informatyczne zyskują coraz

\section{Introduction}

The concept of "smart", referred to the broadly understood process of shaping space, largely pertains to advanced information transfer technologies ${ }^{1}$ that affect the operation of various institutions and the process of gathering and adapting necessary knowledge $^{2}$. Information constitutes a particularly valuable asset, one that can often be the deciding factor in economic superiority or faster economic development $^{3}$. As a consequence, information technology has been increasing in significance in various fields of life all around the world, the discipline of spatial development being one of them.

* Dr inż. arch. Wojciech Korbel, Zakład Przestrzeni Urbanistycznych, Instytut Projektowania Urbanistycznego, Wydział Architektury Politechniki Krakowskiej / Ph.D. Arch. Wojciech Korbel, Division of Urban Spaces, Institute of Urban Design, Faculty of Architecture, Krakow University of Technology, email: arwuka@poczta.onet.pl 
większe znaczenie w różnorodnych dziedzinach życia, równiez $\mathrm{w}$ dziedzinie rozwoju przestrzennego.

Na tym tle, $w$ kreacji polityki przestrzennej polskich gmin pojawia sie jednak szereg, dostrzeganych coraz licznie problemów. Rosnące w postępie geometrycznym moż liwości technologiczne, związane z przekazem informacyjnym, wydają się powoli przerastać możliwości ich faktycznego wykorzystania. Coraz silniej zauważa problemem jest ilość generownych informacij i moann promaniczona zdolnó́ć do ich rzeczywistej absorpocno

Praca podejmuje więc próbę analizy wybranych problemów przepływu informacji $i$ ich skutków $w$ bieżace pracy samorządów nad kształtowaną przez nie polityka przestrzenną.

\section{Elementarne problemy przepływu informaci}

W polskich realiach systemowych, dominujacą role w ksztattowaniu polityki przestrzennej pełnią władze samorządowe gmin, a realizowane przez nie zadania włas$n e^{4} z$ zakresu planowania przestrzennego $0^{5}$ mają szczególny wpływ na jakość powstającej przestrzeni. Zadania te obejmują między innymi zagadnienia związane z ochroną ładu przestrzennego, a więc odnoszą się do ksztaltowania przestrzeni, która winna "tworzyć harmonijna całosć oraz uwzględniac w uporządkowanych relacjach wszelkie uwarunkowania i wymagania funkcjonalne, spoteczno-gospodarcze, środowiskowe, kulturowe oraz kompozycyjno-estetyczne" ${ }^{6}$. Instrumentami mającymi szczególne znaczenie $w$ kreacji ładu przestrzennego sa tworzone na szczeblu gmin studia uwarunkowań $i$ kierunków zagospodarowania ${ }^{7}$ oraz powstające $w$ zgodności z tymi studiami, miejscowe plany zagospodarowania przestrzennego ${ }^{8}$.

Znaczenie obu tych dokumentów warunkowane jest jednak spełnieniem dwóch istotnych wymogów, integralnie związanych z procesem przepływu informaciji

Pierwszy wymóg odnosi sie do konieczności udziału spoleczeństwa w pracach planistycznych i do głębokiej potrzeby szerokiej społecznej akceptacji proponowanych przez władze samorzadowe rozwiazzań.

Drugi dotyczy wiedzy autorów tych dokumentów o licznych (zmieniających się $w$ czasie) uwarunkowaniach systemowych i zasadach ich stosowania, których naruszenie może skutkować poważnymi błędami i nieważnościa tworzonych opracowań, a w konsekwencji marnotrawstwem sił i środków publicznych.

W kontekście obu wymienionych powyżej zagadnień, zdolność efektywnego przekazu informacji w służbie ksztattowania skutecznej polityki przestrzennej nabier wyjątkowego znaczenia.

2.1 Badanie sondażowe - charakterystyka Dla potrzeb analizy przedmiotowej problematyki w marcu 2017 r. przeprowadzono badanie sondażowe $w$ formie ankiety badawczej dotyczącej „sposobu postrzegania
Against this background, there nonetheless appears series of increasingly observable problems in formulation of spatial policy by Pollsh municipalities. Highly increasing technological possibilities related to information transfer seem to slowly surpass the possibilities of their actual us

The amount of information being generated along with the highly restricted capacity for its actual processing both by governments in charge of spatia governance and the local society is becoming an inreasingly observable problem.

Therefore, the work attempts to analyze selected problems of information transfer and their effects in tial policy they shape.

\section{Elementary problems of information flow}

In Polish systemic reality, the dominant role in the shaping of spatial policy is played by the local government authorities of municipalities, with their own $n^{4}$ tasks involving spatial planning ${ }^{5}$ having a particular impact on the quality of emerging space. These tasks include matters associated with protecting spatial order and thus refer to shaping space all functionale a harmonious whole and include tural and compositional and aesthetic condition and requirements in ordered relationships" ${ }^{\prime \prime}$. Instruments that are of particular significance in establishing spatial order are the study of conditions and directions of development ${ }^{7}$ that are drafted a the level of municipalities, as well as local spatia development plan $^{8}$ prepared in accordance with previously mentioned studies.

At the same time, the significance of both documents is conditioned by two essential requirements which are integrally associated with the process of information transfer.

The first requirement refers to the necessity of public participation in planning work and to the basic need for broad public acceptance of solutions proposed by municipal authorities.

The second applies to the knowledge of the authors of those documents with numerous systemic conditions (that change over time) and principles of their application, whose violation can result in considera, esulting in wasted efforts and public funding void, the context of both mentioned above proble

coblems, (n) exceptional significance.

\section{Survey study - a characteristic}

or the purpose of analysing the problem being 2017 in the form of a questionnaire cout in March manner of perceiving spatial planning and construction and development law in force in Poland by municipal authorities in the context of the effectiveness of implementing planned municipal spatial przez władze gminne obowiązującego w Polsce prawa go w kontekście skuteczności realizacji zamierzonego rozwoju przestrzennego gmin oraz oczekiwanych przez samorządy kierunków zmian tego prawa". Ankietę skie rowano bezpośrednio do wójtów, burmistrzów i prezydentów miast, których adresy wylosowano w ramach doboru próby badawczej z pełnego spisu gmin polskich aktualnego na dzień 1 stycznia 2017 r. W ankiecie zamieszczono prośbe by odpowiedzi wimieniu adresató

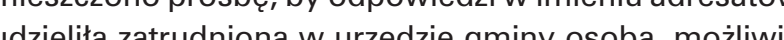
cipelniej zorientowana w problematyce planoziliwi prow rach basa rzyszących kazdemu pytaiu pole zyszaych kaź ub zaproponowac odpowiedz odmienna, wlasna. W obrén we było udzielenie więcej niz jednej odpowiedzi. $Z$ teg względu watosciprocent sumowani do 100

Badanie zrealizowano przy współpracy jednostki badawczo - rozwojowej, specjalizującej się w prowadzeni badań spolecznych. Odpowiadala ona za poprawnoś metodologiczną, dobór próby i wstępne opracowani wynikow. W badaniu wzięly udzial 244 samorządy gminne, stanowiące blisko $10 \%$ wszystkich podstawowych jednostek samorządowych w Polsce. Wielkość dopuszczalnego błędu statystycznego wyniosła $5 \%$.

Z uwagi na szeroki zakres tematyczny ankiety, analiza prezentowanej tu problematyki ograniczona została do związanych z tematem pracy wybranych pytań badawczych i towarzyszących im odpowiedzi.

2.2. Społeczny dostęp do wiedzy o powstających aktach planowania w świetle obowiązującego ustawodawstwa i wyników badania

Dostęp społeczeństwa do wiedzy o podejmowanych prez whadze gmin pracach planistycznych jest co do zaprez widze gmin pracach plady o pod jmowa nych wy o plyowani i zagospo Garowaniu przesizy ustaobliguiac lokalne whadze do stosownego informowan. prasie iw sposob zwyczajowo przyeety soleczenstwa w prasie i w sposob zunczajowo prayjęty w gminie przez okres co najmiej 21 dni ce regulacje prawne nie przewiduja jednak jakiejkolwiek innej formy przekazu informacji adresowanej bezpośred nio do mieszkanców lub waścicieli nieruchomości znajdujacych się $W$ obszarze obejmowanym projektem studium lub planu. W rzeczywistości nie ma więc żadnyc gwarancji dotarcia tych informacji do zainteresowanych osób, o lie osoby te samodzielnie nie sledzą zamieszczanych w lokalnej prasie lub na stronach internetowych obwieszczeń urzędu gminy. W praktyce, poza osobam związanymi zawodowo $z$ procesem budowlano - inwestycyjnym, mało kto wykazuje niezbędne zainteresowanie przedmiotową tematyką. Sytuacja ta owocuje jednak rodzącymi się konfliktami społecznymi wynikającym właśnie z nieskutecznej komunikacji. W tym kontekście, development and the directions of changes to this law expected by local governments". The survey was directly address whose addresses were randomly selected (from the list of Polish municipalities, valid as of 1 January 2017) as a part of establishing the research sample. The survey included a request for the answers to be provided by the municipal offices' employees that have the biggest knowledge about spatial planning problems. The survey's thematic scope was contained in 24 questions. The respondents could use potential answers provided for each question or propose their own. Within the selected questions (prepossible to provide more than be added up to 100

The survey was carried out with the aid of a research The dever was forlity that specialises in carring th ical correctness, sample selection and the initial processing of results. 244 municipal local governments took part in the study, which constitute close to $10 \%$ of all basic local government entities in Poland. The permissible statistical error amounted to $5 \%$.

Because of the survey's broad thematic scope, the analysis of the problems presented here was limited to selected survey questions associated with the subject of the work and their accompanying answers

2.2. Public access to knowledge concerning presenttion and the results of the study

Public access to knowledge about planning work undertaken by municipal authorities is, as a rule, not limited. It is guaranteed by the provisions of the spatial planning and development act which obligate local authorities to appropriately inform the public in the press and in the manner that is customary within the municipality for a period of at least 21 days $^{10}$. Current legal regulations do not, however, feature any other form of information transfer addressed directly to residents or property owners in areas covered by a draft of a study or plan. This is why there is no actual guarantee that such information can the munction or on the office's website. In practice, apert from persons who are professionally associated with the process of construction and real estate development, the number of those who are interested in the subect in question is very small. This situation results in the emergence of social conflicts which arise from ineffective communication. In this context, the survey study that was performed increased knowledge concerning the stance of municipal authorities on the problem of transferring information towards increased public participation and the accompanyin problematic issues.

$32 \%$ of respondents, when answering the question about what is seen as particularly obstructing the 

temat stosunku wladz samorządowych do problematyki przekazu informacji na rzecz zwiększonej partycypac społecznej i towarzyszących zagadnień problemowych. Na pytanie co w sposób szczególny przeszkadza w procesie tworzenia planów zagospodarowania przestrzennego, $32 \%$ ankietowanych władz wskazało na niedostateczne zainteresowanie spoteczne, obserwowane w trakcie sporzadzania projektu planu. Dla $4 \%$ badanych problem byto zbyt duze zainteresowa strony społecznej! 11 Na marginesie warto też odnotować kilka wyrażonych samodzielne opinil, w któnch ankietowani podnosili ele-

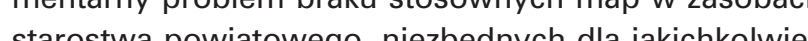
dzieśn pow dzialan planistycznch. Problemz zagania się gminz dostępem do odpowiedniej, cyfrowej bazy danych w skrajnych przypadkach owocuje takze sporami sądowymi ${ }^{12}$ powstajacymi na gruncie regulacji prawnych ksztaltujacych zasady nieodplatnego dostępu do informacji' ${ }^{13}$.

W dalszej części ankiety respondenci pytani byli o potrzebę szerszej zmiany systemu planowania przestrzennego gmin na rzecz poprawy jego skutecznośc i kształtowania lepszej jakości przestrzeni. W udzielanych odpowiedziach, badani niemal w ogóle nie dostrzegli potrzeby większego zaangażowania społeczności lokalnej. Jedynie $6.5 \%$ władz potwierdziło, że w ich opinii niezbędnym jest wypracowanie lepszych (skuteczniejszych) metod konsultacji społecznych np. poprzez wprowadzenie dobrowolnej bazy adresów mailowych osób i firm zainteresowanych informowaniem przez gminę o podejmowanych inicjatywach planistycznych lub poprzez wydłużony (wzgledem ustawowego minimum) okres konsultacji ${ }^{14}$

Ankietowani pytani byli również o oczekiwane ich zdaniem zmiany zakresu ustaleń zawieranych w miejzcawych planach zagospodarowania przestrzennego, mogace sprzyjá poprawie jakości kształtowanei prze

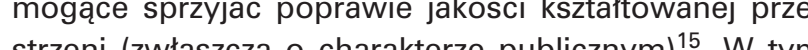
wzgledzie najliziej repez wame samorządowych $(40 \%)$ byla zdania, ze obecny zakres ustalen planow miejscowych jest calkowicie wystarczajacy in wy dostrzegło potrzebę tworzenia koncepcji urbanistycznych, a $12 \%$ uznało wizualizacje przedmiotowych kon-
cepcji jako potencjalne narzędzie lepszych i bardziej zrozumiałych konsultacii społecznych.

Badanie wykazało więc nikłe zainteresowanie samorządów problematyką przekazu informacji na rzec pogłębionej partycypacji strony społecznej w podejmowanych pracach planistycznych. Podnoszona przez respondentow piewszoplanowa problematyka kosztow i czasochłonności procesu planowania ${ }^{16}$, a nawet braku odpowiedniej jakości podkładów geodezyjnych, de fac to uniemożliwia dyskusję o bardziej zaawansowanych rozwiązaniach informatycznych i metodach ich faktycznego zastosowania w polityce przestrzennej gmin. process of drafting local development plans, point(1) ents the problem was an excessive public interest! On a side note, it is also notable that a number of individually expressed opinions in which respondents mentioned the elementary problem of the lack of appropriate maps available to starost offices were reported, said maps being necessary to undertake any planning activity at all. The problem of municipalities facing the lack of access to an appropriate digita database also results in litigation ${ }^{12}$ in some extreme cases, brought about by legal regulations that shape principles of free access to information

Whe following part of the survey, respondents w the asked about the need for a broader change toward impring its space of a better quality In the answers that were provided respondents did not acknowledge any need for a greater involvement of the local com munity at all Only $6,5 \%$ of the surveyed municipa authorities confirmed that, in their opinion, it was necessary to develop better (more effective) methods of public consultation, for instance by introducing a voluntary database of e-mail addresses of people and companies that are interested in being informed by the municipality about any planning initiatives that are undertaken or through an extended (relative to the current legal minimum) consultation period ${ }^{14}$

Respondents were also asked about their expectations concerning any changes to the scope of regulations featured in local spatial development plans that could aid in improving the quality of space (particularly public space) ${ }^{15}$. Here, the group of municipa authorities with the largest number of representatives $(40 \%)$ was of the opinion that the current scope of local planning regulations is completely sufficient and does not need to be changed. Only $15,5 \%$ of respondents observed a need for urban design conceptual proposals, while $12 \%$ considered the visualisation of these proposals as a potential tool facilitating better and more understandThe public consultations.

The survey demonstrated negligible interest among Jocal governments in the problem of information public in planning work. The problem of the costs and time-consuming nature of the planning pross ${ }^{16}$ even the lack of proper survey maps de facto made impossible the discussion about more advanced in formation technology solutions and methods of their actual use in municipal planning policies.

2.3. Access to knowledge about changing legal regulations and legal practice in the application of spatial policy.

The skill of appropriately shaping spatial development policy that is implemented by local governments is closely tied with the need to possess broad
2.3. Dostęp władz samorządowych do wiedzy o zmiewania prawa w realizacji polityki przestrzenne Umiejętność prawidłowego kształtowania prowadzone przez samorządy polityki rozwoju przestrzennego wiaże się ściśle z potrzeba posiadania szerokiej wiedzy $\mathrm{n}$ temat obowiazzujących regulacji prawnych dotyczącyc przedmiotowej materii.

Ta oczywista prawda wymaga jednak nieco głebszej re fleksii wynikajacej z obserwacji regularnie zmieniajacych sie w Polsce licznych uwarunkowán systemowych. Dla przykładu, ustawa o planowaniu i zagospodatowanu

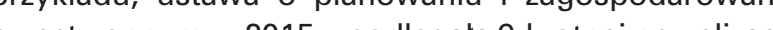
w 2016 r. 5-krotnej, a 2017 r. 3-krotnej. $Z$ kolei ustawa W 2016 r. 5-k

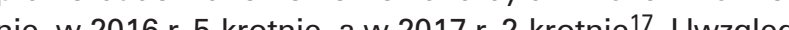
niaj wi

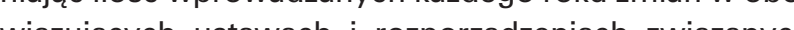
wiazzjących ustawach i rozporządzeniach zwiazzanych integralnie z polityką przestrzenną gmin, umiejętnos gromadzenia i przyswajania wo wasciwym czasie wiedzy dotyczącej obowiązujących regulacji może stanowic dla władz lokalnych powazne wyzwanie. Dla pogłębieni wiedzy na temat analizowanego problemu, do uczestn czących w badaniu wojtów, burmistrzów i prezydentów miast skierowano dwa kolejne pytania.

Wierwszym z nich ankietowani proszeni byli o okrelenie skąd czerpią wiedzę o wprowadzanych w zycie nowych aktach prawa oraz sposobach ich interpretacji. W odpowiedzi $\mathbf{6 0 , 5 \%}$ badanych wskazało na zakupiony przez gminę płatny serwis internetowy. Według 34\% respondentów pozyskiwanie wiedzy leży w zakresie obowiązków wybranych pracowników gminy, pozyskujacych informacje samodzielnie. $30 \%$ badanych czerpie wiedze z rozstrzygniećc sadowych i samorząowych kolegiów odwoławczych, a 18\% z prenumerowanej przez gminę prasy specjalistycznej.

$11 \%$ rzzestników badania przyzn że gmina nie posiada uss potrz pozzkina jedynie okzjo

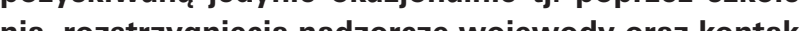
z zatrudnianym dorywczo projektantem planów.

Z zatromadzone wyniki wskazują na relatywnie dużą troZgromadzone wyniki wskazują na relatywnie duzą troskę whadz jodnostek samorządowych o pozyskiwanie wiedzy dotyczącej wprowadzanych w zycie nowych aktow prawa. Obawy budzi jednak ponad piętnastoprocentowy odsetek gmin, w ktorych zasady te nigd nie zostały sprecyzowane. Co więcej, wobec podemowanej tematyki wspólczesnych metod przekaz informacji, szczególne wątpliwości budzi fakt braku jednolitego rozwiązania, gwarantującego dotarcie $\mathbf{n}$ czas niezbędnej wiedzy do wszystkich bez wyjątku, gminnych władz samorządowych. Ułomność ta wydaje się całkowicie niezrozumiała i stanowi ogromną słabosć systemowa.

Szczegółowy rozkład zgromadzonych w toku badania odpowiedzi zaprezentowano na ilustracji 1. knowledge on the subject of current legal regulations concerning the matter being discussed.

However, this obvious truth requires a deeper reflection resulting from an observation of numerous systemic conditions that regularly change in Poland. For instance, the spatial planning and development act was amended nine times in 2015, five times in 2016 and three times in 2017. In turn, the construction law act was amended ten times in 2015, five times in 2016 and two times in 2017 17 . Taking into consideration the amount of changes that are being introduce on a yearly basis to currently enforced acts and ordinances thas are integrally associated with municipal spatial policy, the skill of gathering and gaining appropriate cime contitute quite a challenge for apro an were asked two additional questions.

In the first question, the respondents were asked to define sources of their knowledge about new lega acts and their interpretation.

In response, $60,5 \%$ of the respondents pointed to a paid online service that the municipality had purchased. According to $34 \%$ of respondents, gaining knowledge is a part of the duties of selected employees of the municipality, who obtain information on their own. $30 \%$ of respondents reported that they gather knowledge from verdicts issued by courts of law and local government colleges of appeal, while $18 \%$ reported specialist subscription periodicals purchased by the municipality.

$11 \%$ of the participants of the study admitted that the municipality did not possess established, systemic rules for procuring knowledge, while anoth $6 \%$ pointed to knowledge gained only occasionally, i.e. through training courses, supervision verdicts issued by the voivod and contact with planners who are employed on demand.

The collected results indicate a relatively high concern of local government authorities to acquire knowledge regarding new legal acts being implemented by the state. However, concerns are raised by the $15 \%$ of municipalities in which rules govertion could could guarantee that all municipalties (without particuly worrying. This flaw appeas to be completely inexplicable and constitutes a significant systemic weakness.

The detailed distribution of answers obtained over the course of the survey study has been presented on illustration 1 .

In the second question, the authorities participating in the survey study were asked to answer how they rated the degree of obtaining knowledge about new legal acts entering into force along with their application principles. The essence of the question previous question were bringing the desired results 
wadzonego badania i wykazane w nim problemy natury elementarnej, dalekie od zaawansowanych działan typu "smart", porządkowanie to winno uwzględnić trzy podstawowe działania.

Pierwszym z nich winno być systemowe wzmocnienie w obowiazzujacym ustawodawstwie procesu partycypacji społecznej, kształtujacej polityke przestrzenna gmin. Szczególny nacisk winien zostać położony na wykorzystanie nowoczesnych technik bezpośrednigo przekzu informacii w celu zaggaranto jacym taka wole (mieszańcom, właścicielom nyražającýci ia we mosci itd.) peinego dostępu do wiedzy o podejmowa-

Działaniem drugim winno być opracowanie na szczeblu centralnym systemowego rozwiazania (adresowanego do wszystkich władz samorzadowych), gwarantujacego kompletny przekaz informacyjny o wchodzących w życie zmianach legislacyjnych, ich wzajemnych zależnościach $i$ interpretacjach, zgodnych $z$ intencja ustawodawcy. Rozwiazanie to, w obrebie proponowanych bloków tematycznych takich, jak planowanie przestrzenne, proces inwestycyjno - budowlany czy ochrona środowiska, umożliwiałoby łatwiejsze śledzenie zmian ustawowych i podejmowanie działań planistycznych spójnych z bieżącym porządkiem prawnym. Oba wymienione rozwiązania winny być uzupełnione szerokimi działaniami edukacyjnymi, zwiększajaccym poziom wiedzy społecznej dotyczącej znaczenia ładu przestrzennego, procesów planistycznych, zasad społecznej partycypacji oraz dostępnych nieodpłatnie źródet informacji.

W świetle wyników badania wdrożenie powyższych propozycji wydaje się absolutnie niezbędne. W przeciwnym razie narastać bẹdzie rozdźwięk między rozwijajacym sie, dostepnymi narzedziami informatycznymi, a osiaganymi realnie przeksztatceniami przestrzennymi, opatygo polityce przestrzennej polskich gmin.

PRZYPISY

'Twardowski M., Projekt przyjazny. Smart w przestrzeni rekreacyinej, w.
Housing Environment 19/2017, Wydawnicwo PK, Krakow 2017, s. 86 . 2 Wecclawowicz- Bilska E., Etapy rozwoju miast typu smart, w: Housing
Environment 19/2017. Wydawnicwo PK. Kraków 2017. s. 54 ${ }_{3}^{3}$ Ciechelska A. Poskrobko T. Wptyw inform rozwoj wwarunkach gospodarki iopartej na wiedzy, http: //mikroekonomia net/system
10.02 .2018

Zgodnie z zapisami art. 7 ustep 1 ustawy z dnia 8 marca 1990 r. o samoZäadzie gminnym, Dz. U. z 1990 r. nr 16 poz. 95 z pónniejszymi zmianami zagospodarowaniu przestrzennym, Dz. U. z 2003 r. nr 80 poz. 717 z pózniejszymi zmianami (u.p.z.p.)
6 Godnie z art. 2 p. 1 u.p.z. .
7 Studium uwarunkowań i kie

gminy w rozumieniu art. 9 ust. 1 u.p.p.z.p. Przestrennego w rozumieniu art. 4 ust. u..p.z.p.
${ }_{9}$ Fundacia Rozwoju Badań Spotecznych, Al. Juliusza Stowackiego 6/13 w Krakowie
10 Art. 11 i 17 u.p.z.p.
"1 Korbel W., Instytucja

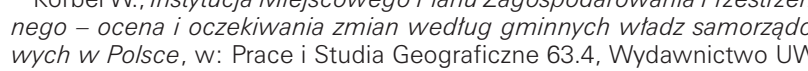
wych W Polsce, w: Prace i Studia Geograficzne 63.4, Wydawnictwo UW. "smart"-type actions, the structuring should feature three fundamental measures.

The first of these should be the systemic reinforcement of the process of public participation that shapes municipal spatial policy in current legislation. A particular emphasis should be placed on using modern direct information transfer technologies in order to guarantee full access to knowledge concerning any planning work undertaken by authorties to everyone who wishes to have it (residents. real estate owners, etc.).

he second action should be the development of a systemic solution at the central level (addressed a all mich sold changes that enter into force, their mutual dopendencies and interpretations, in accodance with the intention of legistators. This solution within the proposed themetic blocks such as spatial planning, real estate development and construction or environmental protection, could make it easier to trace legislative changes and to adopt planning measures in accordance with the current legal order. Both of these solutions should also be supplemented with broad educational efforts increasing the level of public knowledge concerning the significance of spatial order, planning processes, principles of public participation and information sources that are available free of charge.

The results of the study prove, the absolute necess ty for the implementation of the proposals presente above. Otherwise there will be a growing discrepancy between the evolving, available IT tools and rea spatial transformations based on an informative spatial policy of Polish communes deprived of effective communication

ENDNOTES

Twardowski M., Projekt przyjazny. Smart w przestrzeni rekreacy/j
nej in: Housing Environment 19/2017, Wydawnicwo PK, Kraków Wẹctawowicz - Bilska E., Etapy rozwoju miast typu smart, in: Ho-

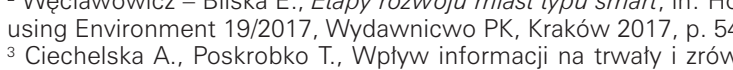
noważony rozwój wwarunkach gospodarki opartej, $n$ a wiedzy.
http://mikroekonomia.net/system/publication__iles/820//original/18.

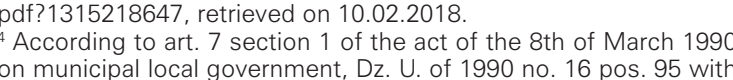
on municipal local government, Dz. U. of 1990 no. 16 pos. 95 wi later changes
5 Scope of activity defined by the Act of the 27 th of March 2003 on
spatial planning and development, Dz. U. of 2003 no. 80 pos. 717 spatial planning and develomments
with later changes (spatial planning and development act). act
7 m municipality's spatial development conditions and directions
study according to art. 9 sectio 1 of the spatial planning and development act

Local spatial development plan according to art. 4 section 1 of the spatial planning and development act
${ }^{9}$ Fundacia Rozwoju Badań Spotecznych, 6/13 Al. Juliusza Stowackiego in Krakow
${ }_{10}$ Art. 11 and 17 of the spatial planning and development act
11 K.

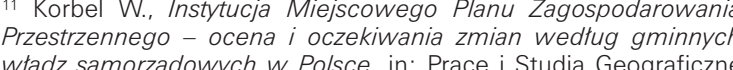
3.4. Wydawnictwo UW. Warszawa 2018, 27 . 27 Geograficzne ${ }^{12}$ Wyrok WSA w Poznaniu z $17.01 .2018 \mathrm{r}$.. sygn. II SA/Po 692/17, w
przedmiocie odmowy przez Starostę powiatowego nieodplatnego
2Wyrok WSA W Poznaniuz z 17.01.2018 r., sygn. II SAPO 692/17, w przednia danych z ewidencii gruntów ibudynków dla potrzeb działan planistycznych gminy (aktualizacii studium)
${ }_{11}^{1}$ Art. 15 , ustawy z dnia 17 lutego 2005 r. o informatyzaciij dziatalności podzmianami
1
4 Korbel W., op. cit., s. 33

${ }_{14}^{14}$ Korbel W., op
15 lbidem, s. 31

16 Ibidem, s. 27

Na podstawie informacji o tekstach jednolitych u.p.z.p... z lat 2015 2017 zawartych w Internetowym Systemie Aktow Prawnych, httrp:///pra
wo.seim.gov.pl/isap.nsf/DocDetails.xpp?id=WDU20030800717, dostep. $30.11 .2017 \%$ r. Fe Meijers E., Smart cities - ranking of European medium-sized cities. Fi nal report, Centre of Regional Science, Vienna University of Technology,
Wiedeñ 2007 .: Nowakowska A., Budowanie intelligentnego miasta. stud

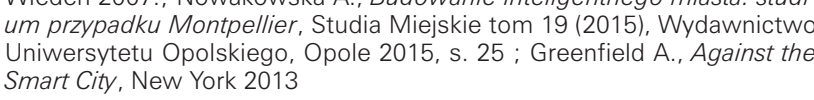
LITERATURA

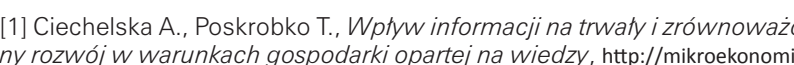

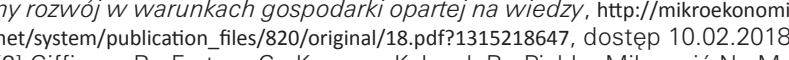

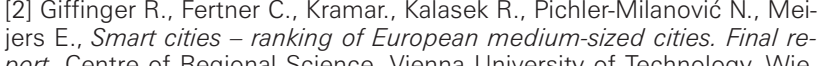
port, Centre of Regional Science, Vienna University of Technology. Wie deń 2007.

[3] Korbel W., Instryucia Miejscowego Planu Zagospodarowania Przestrtrennego - ocena i oczekivania zmian wedtug gminnych wradz samo-
rzadowych $w$ Polsce, w: Prace i Studia Geograficzne 63.4, Wydawnictwo UW, Warszawa 2018, s. 23-39

[4] Nowakowska A., Budowanie inteligentnego miasta. studium przypad
ku Montpellier, Studia Miejskie tom 19 (2015), Wydawnictwo Uniwersytetu Opolskiego, O. Oole 2015 , s. 2.23-34
[5] Ustawa z dia 8 marca 1990 r. o samorzadzie gminnym, Dz. U. z 1990 nr 16 poz. 95 z późniejszymi zmianami nowaniu i zagospodarowani

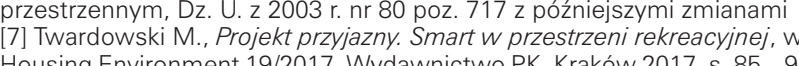
[8] Wẹctawowicz - Bilsk E., Etapy rozworiu miast typu smart, w: Housing udostepnienia danych z ewidencil gruntowi budynkow dia potrzeb

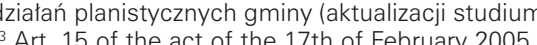
isation of the operations of entitites perforting public tasks, DZ. U.
2005 No. 64 pos. 565 with later changes.

$15 \mathrm{l}$ bidem, p. 31
${ }_{16}^{16} \mathrm{lbidem}, \mathrm{p} .27$

in development act from the years $2015-2017$ eatured in the Online
Legal Acts System, http:///prawo.seim.gov.plisap. nsf DocDetails. 30800717, retriesed on 30.11 . 2017 . .., Meijers E., Smart cities - ranking of European medium-size Technology, Wien 2007: Nowakowska A.. Budowannie inte ligsity go miasta. studumm przypadku Montpellier, Studia Miejkkie vol. 19
2015), Wyddawnictwo Uniwersyytetu Opolskiego, Opole 2015, p. 25

BIBLIOGRAPHY

11] Ciechelska A., Poskrobko T., Wotyw informacili na trwaly i zrón.

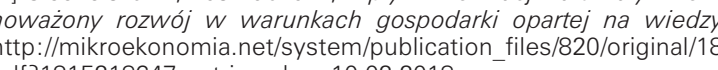
[2] Giffinger R., Fertrner C., Kramar., Kalasek R., Pichler-Milanovic
N. Meijers E., Smart cities - ranking of European medium-size N.t. Meijers E., Smart cities - ranking of European medium-sized
ties. Final report, Centre of Regional Science, Vienna University of

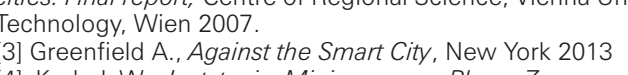

Ki] Korbel W., Instytucia Miescowego Planu Zagospodarowan wadz samorzadowych w Polsce, in in Prace i istudia Geograficzn (j) Nowakowska A Budowana inteli,p. 23.39

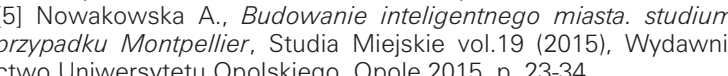
6] Act of the 8th of March 1990 on municipal local governemnt, Dz.

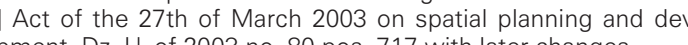
[8] Twardowski M. Proiekt przyjazny. Smart w przestrzeni rekreac eli [9] Wectawowicz-Bilska E.. Etapy rozwoju miast typu smart, in: Ho-
using Environment 19/2017, Wydawnictwo PK, Kraków 2017, p. 54-59 